Interactive comment on "Observing and modelling phytoplankton community structure in the North Sea: can ERSEM-type models simulate biodiversity?" by David A. Ford et al.

M. Butenschön

momm@pml.ac.uk

Received and published: 21 September 2016 


\section{Comment to Ford et al. "Observing and modelling phytoplankton community structure in the North Sea: can ERSEM-type models simulate biodiversity?", Biogeoscience-discussion, 2016}

This work adresses an import aspect of marine ecosystem modelling and spends a commendable effort towards the assesment of the North Sea phytoplankton community structure.

However, with respect to the speculation on the reason of differences in comunity structure in the two models already discussed by the referees, l'd encourage the authors to take into consideration the insights of Sinha et al. 2010, demonstrating the sensitivity of the modelled ecosystem food-web structure to the physical driver alone. These findings are potentially in contrast to the hypothesis that the causes for differences in comunity structure are mainly in the parametrisation of the biogeochemical model, which therefore requires a much more solid base (e.g. simulations using identical physical driver and external forcings).

Printer-friendly version

Furthermore, it should be noted that one of the model versions used in this work (referred to as PML-ERSEM) is based on a parametrisation published in 2004. Since then, other versions and parametrisations of this ERSEM flavour have emerged (e.g. 
the recent works of Butenschön et al. 2016, Ciavatta et al. 2016 and de Mora et al. 2016) that show a distinctively different comunity structure than the parametrisation used in this work (even if for different configurations, see figures 2 and 3 in de Mora et al. 2016 and figure 10 in Butenschön et al. 2016). While I wouldn't expect the authors to repeat their work with a different parametrisation, the fact that the used parametrisation (which is the established one still in use in the operational suite of the UKMO) has evolved since its publication clearly deserves mentioning as these new parametrisations are openly available in the published, peer-reviewed scientific literature.

References:

Butenschön, M., Clark, J., Aldridge, J.N., Allen, J.I., Artioli, Y., Blackford, J., Bruggeman, J., Cazenave, P., Ciavatta, S., Kay, S., Lessin, G., van Leeuwen, S., van der Molen, J., de Mora, L., Polimene, L., Sailley, S., Stephens, N., Torres, R., 2016. ERSEM 15.06: a generic model for marine biogeochemistry and the ecosystem dynamics of the lower trophic levels. Geosci. Model Dev. 9, 1293-1339. doi:10.5194/gmd-9-1293-2016

Ciavatta, S., Kay, S., Saux-Picart, S., Butenschön, M., Allen, J.I., 2016. Decadal reanalysis of biogeochemical indicators and fluxes in the North West European shelf-sea ecosystem. J. Geophys. Res. Oceans 121, 1824-1845. doi:10.1002/2015JC011496

de Mora, L., Butenschön, M., Allen, J.I., 2016. The assessment of a global marine ecosystem model on the basis of emergent properties and ecosystem function: a case study with ERSEM. Geosci. Model Dev. 9, 59-76. doi:10.5194/gmd-9-59-2016

Sinha, B., Buitenhuis, E.T., Quéré, C.L., Anderson, T.R., 2010. Comparison of the emergent behavior of a complex ecosystem model in two ocean general circulation models. Progress in Oceanography 84, 204-224. doi:10.1016/j.pocean.2009.10.003

Printer-friendly version

Discussion paper 